Paideusis

\title{
"Human, All Too Human: A Book for Free Spirits" (Friedrich Nietzsche, Trans. by R.J. Hollingdale. Introduction by Richard Schacht)
}

\section{David Calhoon}

Volume 12, Number 1, 1998

URI: https://id.erudit.org/iderudit/1073100ar

DOI: https://doi.org/10.7202/1073100ar

See table of contents

Publisher(s)

Canadian Philosophy of Education Society

ISSN

0838-4517 (print)

1916-0348 (digital)

Explore this journal

Cite this review

Calhoon, D. (1998). Review of ["Human, All Too Human: A Book for Free Spirits"

(Friedrich Nietzsche, Trans. by R.J. Hollingdale. Introduction by Richard

Schacht)]. Paideusis, 12(1), 71-73. https://doi.org/10.7202/1073100ar 


\section{References}

Clandinin, D. Jean et al. (1995). Teachers' Professional Knowledge Landscapes. New York: Teachers College Press.

Court, Deborah (1994). Book review of William Hare and John P. Portelli, What To Do? Case Studies For Teachers. Paideusis, 8(1).

Portelli, John P. "The Challenge of Teaching for Critical Thinking." McGill Journal of Education, 29(2), (Spring) 1994. Books.

Schon, Donald A. (1993). The Reflective Practitioner. New York: Basic

Trinh, T. Minh-Ha. (1991). When the Moon Waxes Red: Representation, Gender, and Cultural Politics. New York: Routledge.

\section{Friedrich Nietzsche. Human, All Too Human: A Book for Free Spirits. \\ Trans. by R.J. Hollingdale. Introduction by Richard Schacht. Cambridge: Cambridge University Press, 1996.}

\section{David Calhoon, Black Hills State University}

When I began my graduate education in 1987 , I was introduced to a group of writers/thinkers whose work continues to influence my own. Prior to that, names like Heidegger, Gadamer, Hegel, Husserl, Schutz, and Nietzsche meant little to me. The closest I had come to reading the German philosophers was the work of Herman Hesse in the sixties. Even in graduate school, I might not have been drawn to writers like these if it were not for some very good introductions. It was in classes with David Smith, Ted Aoki, and Max Van Manen that I began to encounter these voices from the past seriously. Entering a new field of writing/thinking (with its own challenging language, history and conceptual framework) is almost like meeting a stranger whom I might not be immediately drawn. If the writing is initially obscure, I must decide if the reading (and re-reading!) is worth the effort. However, as with the stranger, a good introduction makes all the difference. If a trusted friend introduces me to new people and extols their virtues, I make the extra effort to get to know them.

I use this metaphor of encountering strangers because it relates to what is, perhaps, a weakness in my own orientation toward reading. I seem to have a need to connect with a writer at a personal level in order for their thinking to become meaningful to me. I am often able to do this through reading interviews or biographical/autobiographical texts. Paulo Friere became much more accessible to me after reading Macedo's interview where Friere speaks of his pleasure in food, wine, and conversation with his friends and loved ones (Friere \& Macedo, 1985). Alfred Schutz became more real to me after reading things he had written about his music and his somewhat tongue-in-cheek phenomenological reference to sexual intercourse as a "face-to-face" relationship (Schutz, 1970). It was not until I read some of Heidegger's reflections on the poet, and sensed his envy of the poet's ability to speak the unspeakable, that I began to relate to him as a fellow human being (Heidegger, 1959).

And so it was with great interest that I accepted the opportunity to review the new edition of Nietzsche's collected aphorisms entitled Human All Too 
Human with its new introduction by Richard Schacht. I thought that, at last, I might learn something of the human side of a writer who had remained elusive to me through the reading of both biographical and autobiographical texts. I was not disappointed!

In his wonderful introduction to this edition, Richard Schacht became that "trusted friend" who introduced me to a side of Nietzsche I had never met. Indeed, the care with which he crafted the twenty-three pages of introduction has much of the spirit of a person who is preparing you to meet an eccentric friend of theirs, about whom they care deeply by warning you of their eccentricities, telling you a bit about the life that shaped them, and encouraging you to look deeper than your first impressions. While providing enough of a biographical overview to be helpful to someone new to Nietzsche, Schacht resists the temptation to get bogged down in the tragic details of the man's life. Instead, he focuses on Nietzsche's writing life and, in particular, the very important role Human, All Too Human played in Nietzsche's life and works. This is followed by Schacht's nicely annotated and categorized suggestions for further reading. To Schacht's credit, the introduction provides valuable information for the uninitiated, as well as challenging new insights for scholars.

However, an introduction can only take you so far. It is aphorisms themselves - nearly 1400 of them (!)-that really afford readers the opportunity to add to their understanding of Nietzsche, both as an intellect and a person. Schacht defines aphorism as "short observations and reflections ranging from one to two sentences to a long paragraph, of a relatively self-contained nature" (p. ix). This collection contains aphorisms ranging from short pithy commentaries like, "Never to speak about oneself is a very noble piece of hypocrisy" (p. 181), to reflections of as much as 1500 words on subjects like religion, politics, and the arts. Written during a span of his life when he was plagued with physical illnesses, these aphorisms give testimony to a mind and a will of astounding vitality.

In ways perhaps not possible in biography or autobiography, Human, All Too Human allows the reader to look straight into the incredible complexity of a brilliant mind given free reign to think whatever it is capable of thinking, with the pen acting as the recorder of those thoughts. The aphorisms paint a picture of a person who is arrogant and humble, vain and self-satirizing, doggedly pessimistic and hopelessly optimistic, cynical and romantic, sarcastically cutting and wistfully poignant, coldly analytical and passionately irrational, cruel and compassionate, consumed with prejudice and filled with tolerance and understanding-in other words, human, all too human. In the midst of these 1400 reflections, Nietzsche has hidden what may be a key for both reading and knowing him. Allow me to give Nietzsche the last word:

Love as artifice. He who really wants to get to know something new (be it a person, an event, a book) does well to entertain it with all possible love and to avert his eyes quickly from everything in it he finds inimical, repellent, false, indeed to banish it from mind: so that, for example, he allows the author of a book the longest start and then, like one watching a race, desires with beating heart that he may reach his goal. For with this procedure, one penetrates to the heart of the new thing, to the point that actually moves it: and precisely this is what is meant by getting to know it. If one has got this far, reason can afterwards make its reservations; that over-estimation, that 
temporary suspension of the critical pendulum, was only an artifice for luring

forth the soul of a thing. (Aphorism 621, Volume I, p. 196)

\section{References}

Friere, P., \& Macedo, D. (1985). Literacy: Reading the Word and the World. Amherst: Bergin \& Garvey.

Heidegger, M. (1959). An Introduction to Metaphysics. New Haven: Yale University Press.

Schutz, A. (1979). On Phenomenology and Social Relations. Chicago: University of Chicago Press. 